\title{
Meat quality of sheep in relation to nutrition at low input
}

\author{
HD Matthes, S Demise, K Ender, K Nürnberg
}

Research Institute for the Biology of Farm Animals Dummerstorf-Rostock, 18196 Dummerstorf, Germany

The purpose of the present study was to investigate meat quality of several lambs genotypes raised on extensive pasture. The effect of grazing pasture on traits (area, colour, intramusculare fat) of musculus longissimus dorsi were determined.

Data were collected from 4 genotypes of lambs (males and females: Black Heads (SKF, $M=16 / 23$ ) ; SKF $\times$ Merinolongwool (ML, $n=22 / 18$ ); Moorschnucken (MS, $n=22 / 18$ ); Black Face $\times$ ML (BF $\times$ ML ; 10 males only). Lambs were allowed to graze on unfertilized pasture with their dams in April and were slaughtered at an average age of 180 days at the end of October.

The following methods were used for the investigation of the different traits of muscle longissimus dorsi : area by planimetry; colour by Minolta ; intramuscular fat by gravimetry after specific extraction of lipids ; fatty acid (FA) composition by gas liquid chromatography. The data were analysed using the GLM procedure of SAS.

The average daily gain $(\mathrm{g})$ of males/females SKF, SKF $\times$ ML, MS and BF $\times$ ML lambs was $149 / 139,179 / 164,125 / 118$ and $180 / 171$ respectively. These results showed the possibility of increasing the quantity of meat produced through commercial crossing ewes with Black-Head or Black-Face rams. Furthermore, grazing of fattening lambs on rangeland with low-quality forages (under extensive management conditions) could not allow to reach the optimal muscle growth (area of muscle longissimus dorsi). Optimal growth rate of lambs could be achieved either with high-quality forage or concentrate feed supplementation at the end of the fattening phase.

There were slight differences $(P<0.05$ in most cases) between breeds in the area, and colour of musclus longissimus dorsi and intramuscular fat content (table). The ratio of saturated to unsaturated FA in intramuscular fat was not significantly different between breeds and sex (males/females: SFK 1.1/1.0; SKF $x$ ML $1.0 / 1.0$; MS 1.0/0.9) whereas the ratio of saturated to polyunsaturated $F A$ slightly differed (males/females : SFK 5.9/5.3 ; SKF $\times$ ML 4.2/6.2; MS 6.2/6.9). Finally, the linolenic acid content of intramuscular fat was higher in lambs raised on extensive pasture (without concentrate feeding) than in lambs supplemented with concentrate. These results agreed with those published in the literature: Saloman et al, 1992, J Anim Sci (0.54) ; Lough et al, 1962, J Anim Sci (0.78) ; Kemp et al, 1981, J Anim Sci (0.9) with concentrate feeding, compared with 2.2 without concentrate feeding.

\begin{tabular}{|c|c|c|c|c|c|}
\hline traits & sex & SKF & SKF $\times$ ML & MS & $\mathrm{BF} \times \mathrm{ML}$ \\
\hline Area $\left(\mathrm{cm}^{2}\right)$ & $\begin{array}{l}m \\
f\end{array}$ & $\begin{array}{r}10.9 \mathrm{ac} \pm 1.8 \\
10.2 \pm 1.7\end{array}$ & $\begin{array}{r}10.1 \mathrm{bc} \pm 1.6 \\
10.6 \pm 1.9\end{array}$ & $\begin{array}{r}9.1 \mathrm{~b} \pm 1.5 \\
10.3 \pm 2.2\end{array}$ & $\begin{array}{c}11.9 \mathrm{~b} \pm 1.7 \\
\text { ND }\end{array}$ \\
\hline Intramuscular fat & $\begin{array}{l}m \\
f\end{array}$ & $\begin{array}{l}1.8^{\mathrm{a}} \pm 0.9 \\
2.4^{\mathrm{a}} \pm 1.0\end{array}$ & $\begin{array}{l}1.9^{\mathrm{a}} \pm 0.9 \\
2.4^{\mathrm{a}} \pm 0.8\end{array}$ & $\begin{array}{l}3.9 b \pm 1.2 \\
3.7 b \pm 1.1\end{array}$ & $\begin{array}{c}1.9 \mathrm{a} \pm 0.8 \\
\mathrm{ND}\end{array}$ \\
\hline Colour of muscles (L) & $\begin{array}{l}m \\
f\end{array}$ & $\begin{array}{r}35.0^{a} \pm 2.4 \\
32.9 \pm 3.6\end{array}$ & $\begin{array}{r}33.9 \text { ac } \pm 3.6 \\
33.5 \pm 1.8\end{array}$ & $\begin{array}{r}31.0^{b} \pm 1.9 \\
31.3 \pm 2.4\end{array}$ & $\begin{array}{c}31.80 c+1.8 \\
N D\end{array}$ \\
\hline Linolenic acid ( $\%$ totalFA) & $m$ & $\begin{array}{l}1.7 \pm 0.4 \\
1.8 \pm 0.4\end{array}$ & $\begin{array}{l}2.0 \pm 0.5 \\
1.7 \pm 0.2\end{array}$ & $\begin{array}{l}1.8 \pm 0.2 \\
1.6 \pm 0.1\end{array}$ & $\begin{array}{l}\text { ND } \\
\text { ND }\end{array}$ \\
\hline
\end{tabular}

Means with different superscripts are significantly different $(P<0.05)$; ND $=$ not determined 